\title{
Teaching resilience: a narrative inquiry into the importance of teacher resilience
}

\author{
Angela Vance $^{\mathrm{a} *}$, Donna Pendergast ${ }^{\mathrm{a}}$ and Susanne Garvis ${ }^{\mathrm{b}}$ \\ ${ }^{a}$ School of Education and Professional Studies, Griffith University, Mt Gravatt, Australia; \\ ${ }^{b}$ Department of Education, Communication and Learning, University of Gothenburg, Gothenburg, \\ Sweden
}

(Received 14 May 2015; final version received 14 July 2015)

\begin{abstract}
This study set out to explore how high school teachers perceive their resilience as they teach a scripted social and emotional learning program to students with the goal of promoting the resilience skills of the students in their pastoral care classes. In this emerging field of research on teacher resilience, there is a paucity of research regarding the resilience of high school teachers in regard to the roles they must fulfill outside of their main function as a subject specialist teacher. In particular, a key role of pastoral care teacher is often layered on to teacher work and there is little professional support provided. This qualitative study took place over eighteen months in an independent faith-based Preparatory to Year 12 School in Queensland, Australia. It employed a narrative inquiry case study that engaged with teachers, managers, and parents. The data collection consisted of a series of three in-depth interviews for each of the seven participant teachers, field notes, and a researcher journal. The data are analyzed by reflecting the themes that occur in the teachers' stories. The findings reveal that these high school teachers had some tacit knowledge of their resilience, that is, they identified common factors from the literature that constitute resilience in their personal life; however, they did not explicitly apply this knowledge to their professional practices.
\end{abstract}

Keywords: pastoral care; teacher resilience; student resilience; narrative

\section{Introduction}

Using effective social and emotional learning (SEL) programs high school teachers can provide valuable opportunities for students to engage in specific tasks that target social skills and resilience (Cahill, Beadle, Farrelly, Forester, \& Smith, 2014). There is a gap in the literature regarding the capacity of teachers to teach SEL, with the majority of studies looking at high school teachers teaching specific subjects or teaching practices in specific areas, for example, literacy (McTigue, Washburn, \& Liew, 2009). Nor is there an answer as to how to train subject specialist teachers in relation to the teaching of SEL (Kimber, Skoog, \& Sandell, 2013). It is in this context that this study was undertaken, thereby seeking to provide insight into the experiences of high school teachers in a pastoral care role delivering SEL programs.

\footnotetext{
*Corresponding author. Email: angela.vance@griffithuni.edu.au
} 


\section{Literature review}

Despite the multidisciplinary interest in resilience, there is not one clear defining sentence, no universally agreed definition (Earvolino-Ramirez, 2007). In the first instance, the discipline from which the researcher approaches the construction of a definition will determine whether resilience will be viewed as an internal characteristic or something that is impacted upon by external events (Herrman et al., 2011). This is an important factor for educational researchers because students and teachers exist as individuals in complex organizations engaged in dynamic processes. Throughout the literature are common factors such as connectedness, belonging, coping skills, strong interpersonal skills, proactive problem-solving skills, and lifelong learning that are deemed to promote resilience (Centres for Disease Control \& Prevention, 2009; Christiansen, Christiansen, \& Howard, 1997; Earvolino-Ramirez, 2007; Hess \& Copeland, 2001). Also cited are environmental factors, including the support network offered to teaching staff, particularly new teachers (Mansfield, Beltman, Price, \& McConney, 2012).

In one study of teachers and resilience, the definition developed was 'the process of, capacity for, or outcome of successful adaptation despite challenging or threatening circumstances' (Pearce \& Morrison, 2011, p. 48). With varied and complex definitions of resilience and the herculean task faced daily by teachers, it is not surprising that 'few studies have examined how teachers understand resilience or how they would describe resilient teachers' (Mansfield et al., 2012, p. 359). This is particularly relevant for subject specialist teachers in high school as they undertake a pastoral care role and are tasked to teach resilience building skills to students.

The pastoral care provided by the teacher, as a product of teaching, is directly related to the academic achievement of students (Nadge, 2005). Relationships are identified as a significant factor in resilience research (Doll \& Lyon, 1998; Howard \& Johnson, 2000; Rutter, 1987) and the relationship between teacher and student is highly significant (Cefai, 2004). The caring and support that a student receives will significantly impact upon a students' resilience (Howard \& Johnson, 2000). For many students, high school is not an ideal environment in which they as adolescents can achieve success, and with the current focus on results in schools, students need support to focus on individual achievement (Bernard, 2007). Increasingly then, schools, therefore, must provide not only opportunities for students to feel supported and safe, but also to have access to people (teachers) who care about them in what they see as 'special relationships' (Howard \& Johnson, 2000, p. 331).

The You Can Do It! Education (YCDI) Program is just one of a number of SEL programs, (e.g. Mind Matters, Bounce Back, Aussie Optimism) that have been developed as learning materials for use in schools. The development of these programs stems from research that demonstrates that adolescents with a delay in their social and emotional development are likely to experience social and emotional difficulties; however, the implementation of SEL programs in schools can promote a variety of improvements in outcomes for students (Bernard, 2007). YCDI offers a scripted sequential curriculum Preparatory to Year 12 program that has a home-school approach for developing the SEL capabilities of students through a concentration on five core skills: confidence, persistence, organization, getting along, and emotional resilience. Focusing on ways of thinking or 'Habits of the Mind' (Bernard, 2007), the program teaches students how to challenge a negative mind-set, thereby influencing emotions and behaviors. 


\section{This study}

The focus of this study is to look at how high school teachers perceive their resilience as they teach a scripted SEL program to students with the goal of promoting the resilience skills of students in their pastoral care classes. Teachers' self-perception is pertinent to how they relate to students given that it is the closeness of that relationship that enhances student learning (Cahill et al., 2014; Hattie, 2004; Howard \& Johnson, 2000).

\section{Method}

This qualitative study took place over eighteen months, in an independent faith-based Preparatory to Year 12 School in Queensland, Australia. The school has a proactive approach to the promotion of student well-being and through the scheduled pastoral care classes in Years 10 to 12 implemented the teaching of the SEL program called YCDI (Bernard, 2007). The high school teachers, in their role as pastoral care teachers, volunteered for the study and are listed on Table 1; they are subject specialist teachers in Humanities, Science and Technology. Ethical approval was sought and pseudonyms are used for the seven teacher participants in order to ensure anonymity. The case study research employed a narrative approach. Underpinned by Clandinin and Connelly (1990, 1996, 2000) and Craig's (2007) perspectives of narrative, data collection consisted of a series of three in-depth audio recorded and transcribed interviews for each teacher participant, field notes, and a researcher personal journal. The half-hour-long interviews took place during school hours in a private meeting room over eighteen months. The researcher kept ongoing field notes when the interviewees engaged in conversations detailing personal feelings and professional practices on topics discussed in the interviews. The researcher maintained a reflective journal to document inner thoughts and feelings experienced as emotional topics were often shared in the interviews. It is the experiences of these teachers, in their pastoral care role only, that will be discussed in this article.

In-house training of the YCDI Program was conducted by the researcher as the trained trainer for teachers with a pastoral care role. A one-hour staff meeting, per term, of non-contact time was allocated for planning. Lessons consisted of one twenty-fiveminute session per week for classes of approximately 16-20 students. The expectation was that the social and emotional language from these lessons would permeate subject specialist classrooms because pastoral care teachers are also subject teachers (Centres for Disease Control \& Prevention, 2009).

Table 1. Teacher participants.

\begin{tabular}{lc}
\hline Head of house & Benny \\
Head of house & William \\
SEL teacher & Tom \\
SEL teacher & Richard \\
SEL teacher & Harold \\
SEL teacher & Jane \\
SEL teacher & Jennifer \\
\hline
\end{tabular}




\section{Narrative inquiry}

The narrative inquiry approach was selected for this study because it offered a specific way of conducting the data collection and analysis that resonates with the needs of this study. Bruner (1991) argues that experiences and memory of human happenings are organized mainly in the form of narrative, which is an account of events occurring over time and the passage of time is itself socially constructed (Clandinin, 2006; Pinnegar \& Daynes, 2007). In this way, narrative inquiry is a way of thinking about experience (Clandinin, 2006). As people's ideas, thoughts, and feelings are based on their experience, then the narrative approach was ideally suited to this study (Craig, 2007).

In narrative inquiry, there exists a relationship between the researcher and the researched and experiences are exchanged and learned from (Craig, 2007; Pinnegar \& Daynes, 2007). The researcher is not observing objectively from the outside but is a participant in the social world of the researched (Clandinin \& Connelly, 2000; Craig, 2007). The whole situation is dynamic, making it compelling and interesting (Craig, 2007). The products of the study were therefore co-constructed and are recounts of people's personal thoughts on their personal and professional experiences, making these experiences central to the focus of the research.

\section{Thematic analysis - narrative threads}

Narrative analysis was chosen because theorists believe that 'human experience is a narrative phenomenon best understood through story' (Craig, 2007, p. 173). In the educational setting, teachers tell stories, and in these stories, they are actors in each other's stories on their professional knowledge landscape (Craig, 2007). While searching these stories for meaning, it has become clear that stories have different purposes and outcomes depending on the reason they are told (Hardin, 2003). Attempting to locate themes in the interviews, the conversational nature of the questions was pertinent to determine whether there had been unwitting prompts toward preferred responses (Hardin, 2003). These 'themes' or 'narrative threads' are woven throughout the transcripts, field notes, and the researcher's personal journal (Clandinin \& Connelly, 2000). Field notes were used to record things participants discussed with the researcher outside the interview that added meaning or clarified something they had said.

The context of the study has been conveyed to provide clear links between the experience and the context because the "embeddedness of the teacher in a school and school system and its mandated curricula, ideologies, pedagogical trend, and reform process needs to be taken into account' (Clandinin, 2007, p. 360). Central to narrative research are the voices of the teachers, without whom meaning cannot be constructed (Clandinin, 2007). Their voices carry 'the many layers of meaning that are embedded in the interpretation of past events' (Clandinin, 2007, p. 373).

\section{Discussion}

The overarching focus of the study was teachers' perceptions of their own resilience as they taught a scripted SEL program because little is known of 'how teachers view resilience in the context of their profession' (Mansfield et al., 2012, p. 358). The resilience building skills developed through the YCDI program are confidence, persistence, organization, getting along, and emotional resilience (Bernard, 2007). As the interviews and researcher's reflections occurred during term time as a specific unit from the SEL 
program was being taught, conversations began around these topics. Following is an insight into the teachers' experiences where appropriate direct quotes are used to depict participants' verbatim comments.

\section{Resilience: first thoughts}

When asked to describe their perception of their own resilience, Tom, Harold, Richard, and Jane echoed a statement made by Jennifer, 'You don't really think about it'. Tom, upon pondering, sees his resilience as being 'able to respond in a positive way to negative events'. With prompting, Tom expresses his resilience as needing to have the confidence and communication skills to resolve an issue. Benny articulates his resilience in terms of his personal life as opposed to his professional practices. In his teacher story, he purports that teaching is practical and university training is only concerned with theory, so he had to pick everything up 'on the job'. He struggles to define resilience as a concept, rather seeing it as an 'emotion', something he believes cannot be taught. Benny fails to identify that he has been resilient in his professional role as a teacher, having achieved promotion to middle management in his third year out of university. Nevertheless, he 'rolls with the punches' and sees his resilience as a 'work in progress'. On the other hand, William sees his resilience as being embedded in his vocation, in his teacher story, coupled with his desire to 'meet kids where they are at'. His teacher story keeps him going even when he feels exhausted. William's teacher story, in essence his vocation, is one of rural placement, changing locations, teaching in different subject areas, complemented by a 'she'll be right mate attitude'.

These teachers can express a generalized, generic concept of resilience in their own words but it takes prompting, reflection, and deconstruction before they can identify the explicit skills that they themselves possess. Nevertheless, they display tacit knowledge as they talk about their resilience where tacit knowledge is taken to mean an ability to perform skills without being able to explicitly articulate them (Pozzali, 2008). None of these teachers use the language of the program being taught to students. All of the teachers relate their resilience to particular events in their personal lives, events they perceive to be difficult, or as Benny describes it 'bad stuff'.

\section{Confidence, self- efficacy, and being able to cope}

Research into teacher resilience has identified confidence as a factor (Gu \& Day, 2007; Mansfield et al., 2012). This confidence can have two aspects: confidence in their capacity to teach, that is, teacher self-efficacy and confidence in their ability to take risks (Mansfield et al., 2012). Teacher efficacy may be defined as 'teachers' belief in their ability to influence valued student outcomes' (Wheatley, 2005, p. 748). In each teacher's narrative, it is evident that they have self-efficacy in relation to their specialist subject areas. Benny sees himself as an effective teacher and when one is a 'good teacher the resilience activity comes out in your teaching'. The other teachers are also confident in their teaching capabilities, positioning themselves as good practitioners with a clear vocation 'meeting kids where they are' declares William, with good knowledge of the students in their classes through maintaining contact with popular culture says Jennifer, and good support from their teaching colleagues "who are people you make friends with' according to William. It appears that they query their ability to influence student outcomes and this has influenced their thinking about what can be achieved by teaching the SEL program. 
The teachers are forthright in articulating their perception that teaching is getting harder. Jennifer makes her first years in teaching sound easy in that she just 'had to rock up' and now she feels 'over it' because of her perception she is letting the students down due to pressures being put on her in both her subject area and the added responsibilities for student well-being in her role as pastoral care teacher. Tom feels he was respected in his early career but talks about being jaded regarding how much is being asked of him outside of the classroom. He knows he is confident and felt he could cope well in the past when his professionalism was not questioned; nowadays, he is exasperated by the questioning from the administration and parents who come with what he terms 'incorrect information'. He believes the story told by the student is believed in preference to the teacher's record of events.

The teachers' claim that their self-efficacy is being challenged in relation to the interactions they have with students and with each other, and in relation to their roles as teachers of SEL and this is slowly spilling into their efficacy beliefs in their specialist subject areas. For example, Tom explicitly refers to a feeling of mistrust and suspicion regarding what he sees as direct control over what he does in the classroom. Harold, too, refers to the pressure of being micromanaged, stating the word 'micromanaged' on five occasions during a single interview,

all the micro management it's actually de-motivating. It doesn't tell me I'm an expert with a master's degree. It tells me I'm an undergraduate or a first year who needs to be managed and it says to me there's a level of disrespect.

This has impacted the feelings of community in the school and rattled the teachers' sense of belonging. Teachers feel obligated to agree or be seen as agreeing with ongoing reforms, of which teaching the SEL program is just one element (Craig, 2013).

\section{Persistence, problem-solving, and coping}

Persistence and perseverance are identified factors for personal resilience ( $\mathrm{Gu} \&$ Day, 2007; Le Cornu, 2009; Mansfield et al., 2012). In the teacher stories, persistence is a theme for teachers in their daily routine. As a training teacher, Jane felt like she was 'drowning at university, having to look up words like pedagogy'. However, she did not give up, and while on her practicum placement and in her first position, she received 'super support' and had 'great mentors'. It all 'fell into place perfectly'. Jennifer identifies persistence alongside being prepared as giving her the capacity to say to herself, 'Yeah, I am okay and I can do things'. She exemplifies her problem-solving capacity when, despite having labeled students in her class as non-compliant and resistant learners; she adapted the program to suit their learning style and kept teaching it.

Tom outlines his capacity to cope and persist in his thoughts on how he should develop all his lessons. He firmly believes that schools are becoming too protective of students and that lessons must be 'productive not fair'. He maintains that this has to be where his focus is, not on creating a 'false level environment for all students'. Richard's story of persistence is poignant because he reveals that he has thought about giving up teaching recently. Coming from interstate, he had to adapt to a new curriculum in his subject specialism including new examination practices. He struggled with having to write a new series of lessons for two senior school year levels while teaching full-time. He is buoyed by his sense of achievement and the fact he did not give up. 
Being organized, planning for lessons, and good time management are factors that can lead to teacher resilience (Hargreaves, 1998; Mansfield et al., 2012). Jennifer says that when she is prepared, she feels ready and able to do anything. In her subject area, Jennifer needs to be highly organized as her lessons are practical and time critical. Jennifer's passion for her subject is palpable in the stories she tells about her classes. She knows her students and she knows what they need. Similarly, Tom identifies organization as being very important to his resilience, particularly as he had not been organized in his personal study recently and he had become anxious. When he brought his documents into his classroom to share his story with his pastoral care students, he included the concept of personal accountability in the lesson. He told them that he knew that even with good organization, 'If I failed or if things don't get done, then it all comes back to me'.

\section{Relationships and connectedness}

Social support networks are deemed as significant coping factors for teachers (Howard \& Johnson, 2004). Creating and sustaining strong empathic relationships, both with peers and adults, creates community and provides a sense of belonging or connectedness (Benard, 1993; Centres for Disease Control \& Prevention, 2009; Swinson, 2010). Knowledge of her students is paramount for Jennifer, an absolute proviso for being able to teach the concepts of the SEL program. She does not teach her specialist subject to her pastoral care students and feels detached from them. Yet, to ensure she can connect with them, she watches the movies or television shows they watch.

Tom values relationships with his students, and through sharing his organizational conundrum, he feels he is making connections with them. Richard displays empathy in his role as a teacher telling the story of one student who was struggling with a grade she had received. He wanted her to know that she was not just that grade, '... because everything she felt about herself was invested in her performance'. He wants to know why all teachers don't talk like that. He says 'I think a lot of us teachers don't ... lack that ... actually lack the skill, they don't defuse situations, they amp it up'. What he sees when he looks at his colleagues is 'people with problems' and if they have issues with their own self-esteem, how can they support a student with self-esteem issues?

Benny and William's stories abound with a lack of understanding regarding the vision for the SEL program that the school set out in a published strategic plan, leading to their perception that they are separate from the administration; as demonstrated by comments from them both such as 'they need to tell us where we're going'. Their confusion is identified throughout their stories, in the language they use to describe their perception of management in this school context. Senior administration staff members are 'they' and everyone else is 'us'. This mirrors later how they describe the school and the people in it, the institution becomes an 'it' and the people 'we' (Craig, 2000, p. 14). This application of designations is used in order to delineate separation, management (they) from teaching staff (us) and the school (it) and the staff (we) telling a story of separation and disconnectedness. Some of the teachers in this study feel disconnected from the vision of the leadership team. Their reluctance to engage fully with the SEL program is rationalized by a perceived lack of visible outcomes (D'Zousa \& Hyde, 2007), exemplified by comments from Richard 'we may never see the result of teaching these concepts'. This story of disconnectedness is in direct contrast to research that demonstrates that school connectedness is a significant factor in developing resilience in both students and teachers (Cahill et al., 2014). For all of these teachers, whether they 
had support or not, formally or socially they see relationships both with colleagues and their students as being critical in their resilience in the teaching profession (Herrman et al., 2011).

\section{Summary and conclusion}

By exploring pastoral care teachers' understandings and perceptions of their resilience, it is possible to investigate how they view their resilience as they teach a SEL program. The findings in this study suggest that these teachers understand the rationale for teaching the SEL program to students and have a tacit knowledge of their resilience but have not reflected how to consciously and explicitly unpack these skills as they teach the program. They can relate personal stories of when they previously used the skills in their personal lives but do not link the skills to their current professional teaching practices.

Teaching is emotional work (Hargreaves, 1998) and explicit understanding of how to utilize resilience skills may enhance teachers' professional capacity in the school context and promote the development of these skills in adolescents (Papatraianou, Levine, $\&$ West, 2014). School and the relationships between teachers and adolescents are a 'key characteristic' (Papatraianou et al., 2014) in the development of the resilience skills of these high school students.

This study points to the lack of connection between teachers' resilience capacities in the context of the resilience building SEL program they are delivering. It is fair to argue this reflects just seven teachers in one case study situation, meaning that the findings are not generalizable to other schools particularly those with different socioeconomic or cultural narratives. A further limitation to this study was that the teachers were specifically discussing their resilience in relation to the teaching of a specific SEL scripted program. It would be beneficial for further research to investigate the perceptions of teachers across a wider spectrum of schools as they promote social and emotional wellbeing in students.

This study reveals that the teachers interviewed had tacit knowledge of their resilience. This was primarily in relation to their personal life but they did not explicitly apply this knowledge to their professional practices. Rather than present teachers with rules and models for teaching and learning in regard to SEL programs, it may be more effective to have them reflect on their use of the skills they are trying to teach in the context of where they are being taught. Over time, some of the teachers have begun to do this sporadically and are using personal stories to demonstrate their perceived use of the concept to the students. This method is haphazard, not consistent and possibly will not promote the development of the designated skills because of the lack of fidelity to the program. For teacher reflection on their resilience skills to occur in a consistent way, professional development opportunities for all teachers involved in teaching SEL programs needs to be accessible, affordable, and in line with the program being implemented. Novice teachers in high schools do not receive training in SEL, and as the teachers in this study show, experienced teachers find it a struggle when there is an expectation that they will teach a scripted SEL program in their pastoral care role.

A school's attitude toward SEL will influence the teachers' perception of the delivery of the SEL curriculum. If teachers perceive they are not supported, they will develop certain beliefs about SEL. Schools might want to consider how SEL is envisioned, valued, resourced, delivered, and communicated in relation to other key learning areas. A shared vision of the goals for the community increases teachers' self-belief (Tschannen-Moran \& Hoy, 2007). This is essentially a belief in the collective aims of 
the group and the ability to see those aims to come to fruition. Schools may consider communicating positive beliefs about SEL throughout the school community in order to create positive beliefs among teachers regarding their role as teachers of SEL.

\section{References}

Benard, B. (1993). Fostering resiliency in kids. Educational Leadership, 51, 44-49.

Bernard, M. E. (2007). Program achieve: A curriculum of lessons for teaching students how to achieve success and develop social-emotional well-being (3rd ed.). Oakleigh, Victoria: Australian Scholarship Group.

Bruner, J. (1991). The narrative construction of reality. Critical Inquiry, 18(1), 1-21.

Cahill, H., Beadle, S., Farrelly, A., Forester, R., \& Smith, K. (2014, October). Building resilience in children and young people. Retrieved from www.vic.gov.au: http://www.education.vic.gov. au/about/department/Pages/resilienceframework.aspx

Cefai, C. (2004). Pupil resilience in the classroom. Emotional and Behavioural Difficulties, 9, $149-170$.

Centres for Disease Control and Prevention. (2009). School connectedness: Strategies for increasing protective factors among youth. Atlanta, GA: US Department of Health and Human Services.

Christiansen, J., Christiansen, J., \& Howard, M. (1997). Using protective factors to enhance resilience and school success for at-risk students. Intervention in School and Clinic, 33, 86-89.

Clandinin, D. (2007). Studying teachers' lives and experience: narrative inquiry into K-12 teaching. In D. J. Clandinin (Ed.), Handbook of narrative inquiry: Mapping a methodology (pp. 357-382). Thousand Oaks, CA: Sage.

Clandinin, D. J. (2006). Narrative inquiry: A methodology for studying lived experience. Research Studies in Music Education, 27, 44-54.

Clandinin, D. J., \& Connelly, F. M. (1990). Stories of experience and narrative inquiry. Educational Researcher, 19, 2-14.

Clandinin, D. J., \& Connelly, F. M. (1996). Teachers' professional knowledge landscapes: teacher stories-stories of teachers-school stories-stories of schools. American Educational Research Association, 25, 24-30.

Clandinin, D. J., \& Connelly, F. M. (2000). Narrative inquiry: Experience and story in qualitative research. San Francisco: Jossey-Bass.

Craig, C. J. (2000). Stories of schools/teacher stories: A two-part invention on the walls theme. Curriculum Inquiry, 30, 11-41.

Craig, C. J. (2007). Story constellations: a narrative approach to contextualizing teachers' knowledge of school reform. Teaching and Teacher Education, 23, 173-188.

Craig, C. J. (2013). Coming to know in the 'eye of the storm': A beginning teacher's introduction to different versions of teacher community. Teaching and Teacher Education, 29, 25-38.

D'Zousa, M., \& Hyde, B. (2007). Spirituality of children and young people: A consideration of some perspectives and implications from research contextualised by Australia. International Journal of Children's Spirituality, 12, 97-104.

Doll, B., \& Lyon, M. A. (1998). Risk and resilience: Implications for the delivery of educational and mental health services in schools. School Psychology Review, 27, 348-363.

Earvolino-Ramirez, M. (2007). Resilience: A concept analysis. Nursing Forum, 42, 73-82.

Gu, Q., \& Day, C. (2007). Teachers resilience: A necessary condition for effectiveness. Teaching and Teacher Education, 23, 1302-1316.

Hardin, P. (2003). Constructing experience in individual interviews, autobiographies and on-line accounts: A poststructuralist approach. Journal of Advanced Nursing, 41, 536-544.

Hargreaves, A. (1998). The emotional practice of teaching. Teaching and Teacher Education, 14, $835-854$.

Hattie, J. (2004). It's official: Teachers make a difference. Educare News, 44, 24-31.

Herrman, H., Stewart, D. E., Diaz-Granados, N., Berger, E. L., Jackson, B., \& Yuen, T. (2011). What is resileince? Canadian Journal of Psychiatry, 56, 258-265.

Hess, R., \& Copeland, E. (2001). Students' stress, coping strategies and school completion: A longitudinal perspective. School Psychology Quarterly, 16, 389-405. 
Howard, S., \& Johnson, B. (2000). What makes the difference? Children and teachers talk about resilient outcomes for children 'at risk'. Educational Studies, 26, 321-337.

Howard, S., \& Johnson, B. (2004). Resilient teachers: Resisting stress and burnout. Social Psychology of Education, 7, 399-420.

Jones, P. (2006). Status of pastoral care in schools in the 21st century. Pastoral Care in Education, 24, 64-66.

Kimber, B., Skoog, T., \& Sandell, R. (2013). Teacher change and development during training in social and emotional learning programs in Sweden. The International Journal of Emotional Education, 5, 17-35.

Le Cornu, R. (2009). Building resilience in pre-service teachers. Teaching and Teacher Education, $25,717-723$.

Mansfield, C., Beltman, S., Price, A., \& McConney, A. (2012). "Don't sweat the small stuff:" Understanding teacher resilience at the chalkface. Teaching and Teacher Education, 28, 357-367.

McTigue, E. M., Washburn, E. K., \& Liew, J. (2009). Academic resilience and reading: Building successful readers. In I. R. Association. The Reading Teacher, 62 (pp. 422-432). 0034-0561 print/1936-2714 online.

Nadge, A. J. (2005). Academic care: Building resilience, building futures. Pastoral Care in Education, 23, 28-33.

Papatraianou, L. H., Levine, D., \& West, D. (2014). Resilience in the face of cyberbullying: An ecological perspective on young people's experiences of online adversity. Pastoral Care in Education, 32, 264-283.

Pearce, J., \& Morrison, C. (2011). Teacher identity and early career resilience: Exploring the links. Australian Journal of Teacher Education, 36, 47-59.

Pinnegar, S., \& Daynes, J. G. (2007). Locating narrative inquiry historically: Thematics in the turn to narrative. In D. J. Clandinin (Ed.), Handbook of narrative inquiry: Mapping a methodology (pp. 3-34). Thousand Oaks, CA: Sage.

Pozzali, A. (2008). Tacit knowledge, implicit learning and scientific reasoning. Mind Society, 7, 227-237.

Rutter, M. (1987). Psychosocial resilience and protective mechanisms. American Journal of Orthopsychiatry, 57, 316-331.

Swinson, J. (2010). Working with a secondary school to improve social relationships, pupil behaviour, motivation and learning. Pastoral Care in Education, 28, 181-194.

Tschannen-Moran, M., \& Hoy, A. (2007). The differential antecedents of self-efficacy beliefs of novice and experienced teachers. Teaching and Teacher Education, 23, 944-956.

Wheatley, K. F. (2005). The case for reconceptualizing teacher efficacy research. Teaching and Teacher Education, 21, 747-766. 
This article was downloaded by: [Angela Vance]

On: 22 August 2015, At: 18:54

Publisher: Routledge

Informa Ltd Registered in England and Wales Registered Number: 1072954 Registered

office: 5 Howick Place, London, SW1P 1WG

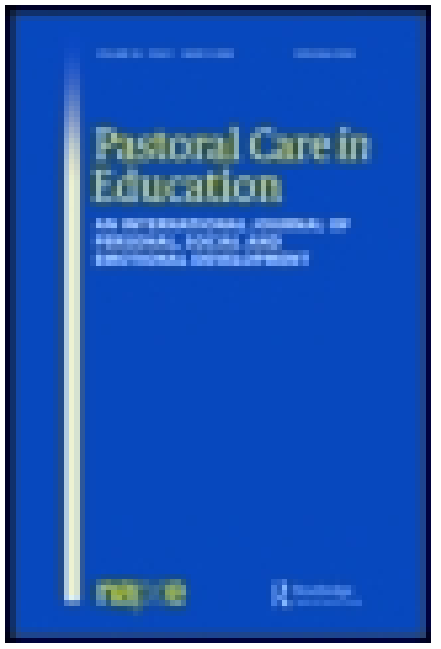

CrossMark
Pastoral Care in Education: An International J ournal of Personal, Social and Emotional Development

Publication details, including instructions for authors and subscription information:

http:// www.tandfonline.com/loi/ rped20

\section{Teaching resilience: a narrative inquiry into the importance of teacher resilience}

\author{
Angela Vance ${ }^{a}$, Donna Pendergast ${ }^{a} \&$ Susanne Garvis ${ }^{b}$ \\ a School of Education and Professional Studies, Griffith University, \\ Mt Gravatt, Australia \\ ${ }^{\mathrm{b}}$ Department of Education, Communication and Learning, \\ University of Gothenburg, Gothenburg, Sweden \\ Published online: 18 Aug 2015.
}

To cite this article: Angela Vance, Donna Pendergast \& Susanne Garvis (2015): Teaching resilience: a narrative inquiry into the importance of teacher resilience, Pastoral Care in Education: An International J ournal of Personal, Social and Emotional Development, DOI: 10.1080/02643944.2015.1074265

To link to this article: http:// dx. doi.org/ 10.1080/02643944.2015.1074265

\section{PLEASE SCROLL DOWN FOR ARTICLE}

Taylor \& Francis makes every effort to ensure the accuracy of all the information (the "Content") contained in the publications on our platform. However, Taylor \& Francis, our agents, and our licensors make no representations or warranties whatsoever as to the accuracy, completeness, or suitability for any purpose of the Content. Any opinions and views expressed in this publication are the opinions and views of the authors, and are not the views of or endorsed by Taylor \& Francis. The accuracy of the Content should not be relied upon and should be independently verified with primary sources of information. Taylor and Francis shall not be liable for any losses, actions, claims, proceedings, demands, costs, expenses, damages, and other liabilities whatsoever or howsoever caused arising directly or indirectly in connection with, in relation to or arising out of the use of the Content.

This article may be used for research, teaching, and private study purposes. Any substantial or systematic reproduction, redistribution, reselling, loan, sub-licensing, systematic supply, or distribution in any form to anyone is expressly forbidden. Terms \& 

and-conditions 